\title{
Editorial
}

\section{Honorary Award of the German-Speaking Child Neurology Society - Gesellschaft für Neuropädiatrie - 2015}

\author{
Barbara Plecko, MD ${ }^{1}$ \\ 1 Department of Child Neurology, University Children's Hospital \\ Zurich, Zurich, Switzerland
}

Neuropediatrics 2015;46:233.

Every year, the German-speaking Society of Child Neurology (GNP) has the pleasure to nominate an awardee with special achievements in the field of child neurology to give a lecture during our annual conference and to receive the prize of our society, kindly supported by Thieme Publishers.

This year, it has been our great delight to have Prof. Linda de Vries (Utrecht) receive this award during our well-perceived GNP conference in Basel organized by Prof. Peter Weber (Basel). Ahead of the lecture Prof. Ulrike Schara (Essen), president of the GNP, announced that following sensible discussions, the board has agreed to rename the award to "Honorary Award of the German-speaking Society of Child Neurology (GNP)" (Ehrenpreis der Gesellschaft für Neuropädiatrie).

Prof. Regina Trollmann (Erlangen) held the honorable laudatio and outlined the professional career of Linda de Vries. Born in Amsterdam, Linda de Vries studied medicine in Groningen and trained as a pediatrician in Utrecht. Soon she was to recognize the importance of long-term outcome of critically ill neonates, and from 1982 to 1987 specialized in neonatal neurology at the Hammersmith Hospital with Lilly and Victor Dubowitz. She passed her fellowship in child neurology at the University of Leuven with Prof. Paul Casear and from then on focused on methods for neuromonitoring of neonates and preterm infants. Her continuous research in this field and publication of over 300 original articles, 4 books, and 30 book chapters, have since made a change in our awareness of neonatal brain injury and the methods for neonatal neuromonitoring. Her open mind for collaborations resulted in many fruitful cooperations such as with Prof. HellströmWestas (Uppsala) on amplitude integrated electroencephalogram, or with Petra Hüppi (Geneva) and Frances Cowan and Mary Rutherford (London) on neonatal neuroimaging.

Since 2010, Linda de Vries is Chair of Neonatal Neurology at the University of Utrecht and adjunct professor in

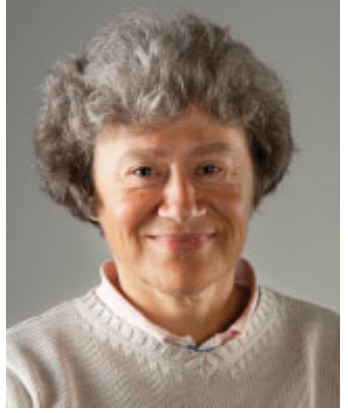

Prof. Linda de Vries

neonatal neurology at the University of California, San Francisco. For her research and visionary work, she has received several international recognitions as the honorary membership of the American Pediatric Society and has been invited for the McCance Lecture of the British Neonatal Society and the Harwood Nash memorial lecture of the University of Toronto.

The audience of the GNP conference in Basel heard a brilliant lecture on the progress of neonatal neuroimaging over the past decades. The content of this lecture is outlined in a review article by Linda de Vries and coauthors in this issue of Neuropediatrics. ${ }^{1}$ While progress in lung maturation and intensive care management reduced the incidence of intraventricular hemorrhage and cystic periventricular leukomalacia, it has been recognized that more subtle changes in the cerebellum or white matter contribute to cognitive and behavioral anomalies of preterm infants. Monitoring of the incidence and timing of these "minor" injuries will help identify underlying risk factors and enable their prevention and treatment.

It is a great honor for our Gesellschaft für Neuropädiatrie (GNP) to welcome Prof. Linda de Vries as an awardee of our society. The audience has been impressed by her academic and pure personality as well as by her utmost expertise and dedication not only to science but also to patients and their families. She ended her lecture in a commitment to our younger colleagues, who by their future research will contribute to answering the many open questions in the field of child neurology.

\section{Reference}

1 de Vries LS, Benders MJNL, Groenendaal F. Progress in neonatal neurology with a focus on neuroimaging in the preterm infant. Neuropediatrics 2015;46(4):234-241

(c) 2015 Georg Thieme Verlag KG Stuttgart · New York
DOI http://dx.doi.org/ 10.1055/s-0035-1558422. ISSN 0174-304X. 